\title{
On the Sexuality and Development of the Ascocarp in Ascophanus carneus, Pers.
}

\author{
$\mathrm{BY}$ \\ E. M. CUTTING, M.A., F.L.S., \\ Assistant in Botany, Birkbeck College, London.
}

With Plate XXVIII.

T N I 906, at Prof. V. H. Blackman's suggestion, I began a search amongst 1 the coprophilous Fungi for a form possessing an ascogonium favourable for working out the developmental features from its inception up to the formation of ascogenous hyphae and asci. About this time Prof. Blackman and Miss Fraser (7) had investigated the Ascomycete Humaria gramulata, and had found that the female nuclei of its unicellular ascogonium fused in pairs, and they expressed the opinion that, in this form, this process takes the place of the ordinary sexual process which had been described by Harper in Sphaerotheca $(18,19)$ and Pyronema $(20)$. In their paper the authors suggested that a similar reduced fertilization might be found to take place in the ascogonium of Ascobolus furfuraceus and other forms.

On the discovery of a well-marked ascogonium, of the type described by Woronin (28) as a scolecite, in an ascocarp occurring abundantly, and in colonial growths on rabbit's dung, it was decided to work out the nuclear features of the life-history of this species.

The colour of this fungus, although varying within somewhat wide limits, is of a quite characteristic fleshy hue. Occurring abundantly on most rabbit's dung, it is not confined to this medium; I have found it growing on earth where there had recently been a fire and forming a patch of so large a size and so densely packed as to give the ground a perceptibly fleshy colour even from a distance of several yards.

From its characters it very obviously belonged to the genus Ascophanus, but some little difficulty was experienced in determining whether the species was carneus or furfuraceus. These two species would seem to be very closely allied, and indeed, Massee, in his British Fungus Flora (23), makes furfuraceus a variety of carneus ; moreover, the description of the two species given in different systematic works cannot be quite reconciled. In this

[Annals of Botany, Vol. XXIII. No. XCI. July, r909.] 
paper I am following the description given in Rabenhorst's Kryptogamen Flora (25), which undoubtedly indicates that the fungus is $A$. carneus. ${ }^{1}$

Miss Welsford (27) has so recently given a summary of our knowledge of the development of the fruits of the Ascobolaceae as to render it unnecessary for me to give a further account here. I cannot find, however, that the fungus Ascobolus pulcherrimus, Cr., the ascogonium of which Woronin (28) described, was ever named Ascophanus pulcherrimus by Crouan. This systematist placed the fungus in the genus Ascobolus, and since then it has been placed in the genus Lasiobolus by Schröter. I cannot find, in any of the systematic works that I have consulted, any trace of its ever being placed in the genus Ascophanus, although Massee (23), in his British Fungus Flora, has placed Lasiobolus equinus, an English species, in the latter genus.

When nearly all the observations recorded in this paper were made, I found a reference to a paper on Ascophanus carneus, Pers., by Miss Ternetz (26). This paper is mostly concerned with the protoplasmic streaming found in the species, but it also shortly describes the fruit development. The account there given agrees very well indeed with what I have found.

Miss Ternetz describes the archicarp as a 'scolecite', and says that it is very variable, both in the number and dimensions of the cells composing it, and also in the amount of curling of the organ. She finds no central cell as in Ascobolus furfuraceus and says that, in some cases, the tip of the ascogonium grows on so that the ascogonium becomes intercalary, and that it is possible that at times the portion that has grown on may form another ascogonium.

She observed no copulation, and says that the wall of the young ascogonium was unbroken. The cells are at first full of dense protoplasm, but after a time are emptied, and could not be found in full-grown apothecia.

\section{Methods.}

Thin slices were cut from the surface of bits of rabbit's dung on which the fungus was growing. These were fixed in Flemming's weak fluid, which was allowed to act for twenty-four hours. The sections were cut $4 \mu$ or $5 \mu$ in thickness and were stained either with the triple stain or with Heidenhain's iron haematoxylin, and, in the latter case, sometimes counter-stained with erythrosin and mounted in Damar Lac.

\section{GERMination OF THE SPORES.}

Many attempts were made at an early period in this work to germinate the spores of this fungus, but these were all in vain. Agar-agar dissolved in rabbit's-dung extract and acidified with orange juice was used in these

1 I have to thank Miss A. Lorrain Smith, of the Natural History Museum, South Kensington, for advice on this and other systematic points. 
cultures. On the appearance of Miss Fraser's paper on Lachnea stercorea (14), in which she describes the germination of the spores of this fungus after treatment with alkaline solutions, it was determined to make more experiments and under divers conditions. De Bary (13) had observed that both acid and alkaline media were sometimes useful in inducing the germination of spores which, under ordinary conditions, could not be made to germinate, so in making solutions, alkaline, acid, and neutral fluids were employed, and the effect of different temperatures was noted as well.

Extracts of rabbit's dung and of prunes were used, and also water. In only one case was a germination observed in an acid medium, although both in acid and neutral solutions the spores were often observed to become more transparent, and a number of vacuoles were noticed inside them, these phenomena being the preliminaries to germination. These changes were observed in spores which had been subjected to a fairly high temperature, $38^{\circ}$ or $40^{\circ} \mathrm{C}$, for a few days. The processes of germination, however, got no further except in the one case mentioned above.

In the alkaline solutions, however, the spores easily germinated over-night, and this process took place more quickly at higher than at lower temperatures, so that a greater percentage of spores would germinate over-night in a high-temperature culture, $38^{\circ} \mathrm{C}$. or $40^{\circ} \mathrm{C}$, than in a lower temperature culture $\left(30^{\circ} \mathrm{C}\right.$. $)$.

No very exact experiments were tried, the only object being to obtain pure cultures of the fungus; but the results obtained seem to show that the germination of the spores depends on the softening process of the alkaline media on the wall, and that this latter process was hastened by an increase in temperature.

The attempt to obtain pure cultures was not successful. In the alkaline media the mycelium only grew to about $\frac{1}{2}$ inch long, and then died away, probably overcome by the bacteria which could not be kept out of these cultures. The germinating spores were also removed to acid media, or acid agar-agar extract of rabbit's dung, but in all cases the mycelium soon perished.

The spores usually put out two germ tubes, one at each end of the spore, and in some cases a transverse wall was formed in the middle of the spore, so that the two germ tubes were to some extent independent of each other. This wall-formation is comparable to the formation of transverse walls such as are found in the ascospores of many ascomycetes, such as Sphaerulina, Coryne, \&c., but here the wall-formation does not take place in the ascus, but is delayed until after the earlier stages of germination are passed.

It was observed in several cases that as a preliminary to the stopping of germination by adverse causes, the protoplasm from the different cells of the mycelium collected either in one cell of the hypha or in the spore itself, 
probably passing through the pore in the transverse wall, which will be described at the same time as the mycelium, and here it was cut off from the adjoining empty cells by pads of material which stopped up the pores in the transverse walls.

\section{Mycelium and Chlamydospores.}

The cells of the vegetative mycelium contain a varying quantity of protoplasm and numerous nuclei (Figs. 6 and 7). The side walls bear a number of spherical granules which Miss Ternetz has already seen and described. These granules seem to be similar to those described in Ascobolus (Harper, 19, Welsford, 27), Pyronema (Harper, 20), Humaria gramulata (Blackman and Fraser, 7), and other Ascomycetes.

Harper (19) has suggested that these bodies are concerned with a transmission of materials from cell to cell, and that they are probably connected in some way with a pore. He does not, however, figure or describe any such pores in Pyronema.

In Ascophamus carneus these granules, which vary very much in number, are situated on either side of a small pore in the transverse walls of the hyphae (Fig. 7). When the sections were stained with the triple stain I was at first unable to be absolutely certain of the presence of this pore, but after staining with Heidenhain's haematoxylin and counter-staining with erythrosin, there was no doubt that the pore was always present in the vegetative hyphae, and I have since seen many well-marked pores in sections stained with the triple stain.

Miss Ternetz (26) recorded that the protoplasm and vacuoles pass from cell to cell in this species, and suggested that there is a pore in the transverse wall. Woronin (28) has described a similar protoplasmic streaming in an allied form, Lasiobolus (Ascobolus) pulcherrimus. This latter species is also provided with granules. Neither of these authors, however, actually saw the pore.

The composition of the granules and the part that they play in the life-history of this fungus is somewhat difficult to determine. Miss Ternetz examined them with microchemical tests, but was unable to come to any definite conclusions as to their chemical nature. She found that neither methylene blue nor iodine stained them, but that nuclear dyes were taken up with great avidity.

I found that, although they were often stained with the safranin of the triple stain, they more commonly took up the gentian violet; they had also the very greatest avidity for Heidenhain's haematoxylin. I tried several microchemical tests as well, but was unable to form any conclusion as to their chemical nature.

As to their function I can only say that under certain conditions 
(usually lack of food material, or presence of sugar $^{1}$ ) certain rows of cells in the vegetative mycelium are differentiated as Chlamydospore-rows, and that in these cases the pores are closed by the granules, which then become surrounded by a common envelope of lightly-staining material closely pressed to the pore.

The granules form a similar pad in certain unfavourable germinations in which the protoplasm retreats from the germ-tube into the spore, and the contents are closed off from the empty cells.

A similar phenomenon is to be seen in the ascogonium; this will be considered more in detail when that organ is being described.

The nuclei in the vegetative hyphae are very small, and are differentiated with great difficulty. They showed signs of a chromatic network and appear to divide karyokinetically, but no details of the process were made out owing to the minuteness of the objects.

\section{Development of the Apothecium.}

Grosser Morphology. The archicarp (Fig. I) arises as a branch of a vegetative hypha. It resembles in shape the organ described by Woronin as a scolecite, and in its young condition the cells composing it are very similar in appearance. As it develops further, however, three fairly definitely marked regions can be distinguished - a basal vegetative part, a central ascogonial, and a terminal vegetative. In some cases this last seems to be absent, but, as this point was determined in the case of ascogonia which were already covered in, it may be that this portion was present in all cases, though at this period unrecognizable in some fruits. The basal vegetative part of the archicarp and the surrounding mycelium send up numerous hyphal branches which quickly envelop the young ascogonium. Each fruit contains, therefore, only one ascogonium.

No trace of an antheridium or of any other kind of male organ was found.

Sometimes the archicarp seems to arise in a dense tangle of 'chlamydospore-rows', suggesting a comparison with Miss Welsford's description of the beginnings of the archicarp of Ascobolus (27).

In Ascophamus carneus the number of cells in each of the three abovementioned portions of the archicarp varies greatly. The basal part may be composed of from three to about a dozen cells ; the precise number, however, can seldom be determined owing to the early degeneration of the cells nearest the parent hypha. These cells are used in contributing towards the formation of enveloping branches for the fruit. Another point which sometimes makes the determination difficult, is the fact that in many cases the ascogonial portion is not marked off from the basal portion until late in the development. 
The ascogonium or part concerned in the formation of the ascogenous hyphae is also composed of a varying number of cells from about three to seven. All these cells are very nearly equal in size, and there is no sign of the presence of any specially differentiated 'central cells' as in Ascobolus furfuraceus.

The terminal portion is sometimes composed of about three or five cells, but at other times it seems to grow on, and Miss Ternetz says that it is capable of growing on and forming an ascogonium, thus giving rise to another fruit. I have very carefully searched my preparations to see if I could find any trace of such a process, but have not succeeded in doing so. It would, however, be difficult to make sure of such a point in sections.

The fruits often occur quite close together, and such cases were carefully examined; but neither in these, nor even in those rare cases in which two ascogonia are seen enclosed in one spherical pseudo-fruit-mass, was there any sign of continuity between two archicarps.

It was found that a fairly large branch was in some few cases given off from about the middle of the ascogonium. This branch agrees in structure with the ascogonial region of the archicarp, and I am inclined to regard it merely as an ordinary branch of that region, and not as a trichogyne or an ascogenous hypha.

\section{Cytological Features.}

The cells of the archicarp, even when in an uncovered condition, are much larger than those of the ordinary mycelium, indeed, they are of about the same size as the cells of the chlamydospore-rows. The protoplasm of these cells is very dense and contains a few large, more or less centrally situated, vacuoles. These contain a number of spherical, highly refringent bodies with no affinity for stains. The cross-walls are perforated like those of the ordinary vegetative cells, and the pores are provided with the characteristic granules (Fig. 4). These cells are multinucleate, and contain many more nuclei than the ordinary hyphal cells (Figs. 2, 3).

Special care was taken in the determination of the number of nuclei present in the cells of the young archicarp because of the claim of Harper (19), confirmed by Miss Welsford (27), but denied by Dangeard (10), that the cells of the archicarp of Ascobolus are uninucleate when first formed. No evidence of such a condition was obtained in Ascophanus. Very numerous nuclei were found in the ascogonial cells, even in the youngest of the uncovered ascogonia which I have seen. This question will be more fully discussed later.

As the archicarp gets covered in, the cells increase in size, and the number of vacuoles increases. The protoplasm gets less dense and the nuclei become more distinct than before. Also about this time a yellow, irregularly spherical body appears in the middle of the ascogonial cells and 
also at times in the cells of the terminal vegetative portion of the archicarp. It is evidently of the nature of food-reserve and is not found in very old fruits (Fig. 5).

The nuclei in the ascogonial region show at this time a well-marked nucleolus surrounded by a homogeneous space and bounded by a nuclear membrane. The nuclei in the basal and terminal parts are in general intermediate in structure between the ascogonial and the ordinary vegetative nuclei. In slightly different stages, however, the nuclei vary in minute details as, for example, in the relative sizes of the nucleolus and the nuclear cavity.

When the archicarp is as yet but slightly covered, the characteristic granules on the transverse walls fuse and form pads which close the pores (Fig. 5).

The apical portion of the archicarp as a rule degenerates early, and with the loss of contents all of the pads disappear, except the one immediately adjoining the transverse wall which separates this region from the ascogonial. This pad is very well marked, and the wall bearing it is usually much thickened (Fig. I4).

In the basal portion of the ascogonium the pads are more persistent and very well marked; so much so as to be often of great service in the identification of this region, especially when the individal cells have to be followed through a long series of sections (Fig. I4).

The pads in the ascogonium soon, and, as far as could be ascertained, suddenly disappear, and with them that portion of the wall around the pore which was covered by them. In this way a very wide secondary pore, about a third of the width of the transverse wall, is formed (Fig. II). The ascogonial transverse walls do not lose their pads simultaneously nor, as far as could be ascertained, in any definite order, but quite irregularly (Fig. 5).

When the whole series of pores is formed, the ascogonium is practically one large cell (Fig. 22) with a varying number of ring-like ingrowths, and it presents a very similar appearance to the adult ascogonium of Ascobolus furfuraceus as described by Harper (19) and by Miss Welsford (27).

The exact manner in which these secondary pores are formed has not been observed. No evidence was obtained for their formation by the gradual widening of the original pores, on the contrary the dissolution of the pads and the formation of the secondary pores seem to have always taken place simultaneously, and this suggests that the two processes are intimately connected. Pads were often found lying free in the cells, and showing indications that they contained the portion of the wall on which they were originally deposited. It is possible that some of these may have been torn away in the process of cutting, but in some cases the transverse wall was at right angles to the razor during the process of sectioning, and this explanation would hardly count here. Often traces of what seemed 
to be a mucilagenous degeneration were seen in the lighter portions of the pad, and it was thought that perhaps the wall underwent some sort of mucilagenous change brought on perhaps by the action of some substance or substances originating in the granule, but as a similar appearance is seen in the basal vegetative cells, and here no secondary pores are formed, it seems likely that this appearance has a different meaning.

The observed facts seem to me to suggest that the pads act, in some way, on the transverse wall, resulting in that portion of the wall on which they are seated coming away with them. This may perhaps be due to some weakening action on the periphery of this portion of the wall.

\section{Fertilization.}

Nuclear fusions were found to take place in the ascogonium, and it was in old ascogonia, with secondary pores, that the process was first studied. At this period, and also at the time of formation of the ascogenous hyphae, the protoplasm is not nearly as dense as in the earlier stages of development, and the nuclei are more easily differentiated.

The fusion stages are as follows:-A pair of nuclei approach each other and touch; the nuclear membranes, at the point of contact, disappear, giving rise to the characteristic dumb-bell-like structure. After this the nuclear membrane takes on a spherical shape, and inside it are to be seen the two nucleoli of the original fusing nuclei (Figs. 8, 9, 10, II, I2, I3). These nucleoli fuse later, going through a dumb-bell stage just as the fusing nuclei themselves have done. The fusion nucleus is easily recognized, both by its size and by the size of its nucleolus.

Nuclei in the first 'contact' stages of fusion are very difficult indeed to distinguish from nuclei in accidental contact, and such stages are comparatively rarely met with. It is probable that the actual fusion-process takes a very short time indeed, owing, partly at least, to the large amount of nuclear sap.

In his paper on Pyronema (20) Harper says that all the fusions take place at about the same time, while Blackman and Fraser (7) report that in Humaria granulata the fusions are spread over a long period of time. In Ascophamus carneus there are epidemics of fusions, that is to say, the fusions seem to last over a long developmental period, and yet when one discovers a fusion stage in an ascogonium many others are almost sure to be found at the same time.

It has already been pointed out that no cell in the ascogonium of this fungus is specially marked out from the others, either by its size, as in Ascobolus, or by any other feature. Corresponding to this, it was found that the fusions were not limited to one cell, as has been described in the latter genus. 
Great difficulty, however, was encountered when an attempt was made to make out whether fusions took place in all of the ascogonial cells. It was found, for example, that fusions might be taking place fairly freely in one or two adjacent cells of the ascogonium, and no signs of fusions in the neighbouring cells. This point could not, therefore, be determined by working at any one ascogonium. It may seem that this difficulty might be got rid of by comparing cells in which fusions were taking place in one ascogonium with those of another ascogonium with fusions, and so obtain a complete series: but the number of cells in different ascogonia, as has already been mentioned, differs greatly, so that no one cell of an ascogonium can be compared directly with any one cell of another, except in those cases where the number of cells is equal. Again, the ascogonia are usually so curled that in sections it is generally very difficult to determine the exact relative position of individual cells. The observations given below point to the probability of fusions taking place in every ascogonial cell or, rather, compartment.

In several ascogonia fusion stages were observed in two cells and, in many others, in three. In one ascogonium as many as five cells were observed containing nuclei in different stages of fusion. Also, although, as mentioned above, it is often difficult to determine the exact relative positions of ascogonial cells, there is no doubt that fusions can take place in all portions of the ascogonium, for such processes have been observed in apical, median, and basal parts.

Miss Welsford (27) in her Ascobolus paper reports fusions only in the middle central cell. It seems to me possible that at least some of the nuclei may fuse before they collect in this large structure, but this possibility does not seem to have been considered.

The observations given above were made on ascogonia, the cells of which were in open continuity by means of the secondary pores, and the mere fact that these fusions are able to take place in each of the partlypartitioned-off cells is no guarantee that the fusing nuclei are nuclei belonging to the cell in which they were observed fusing.

\section{Relationship OF the Fusing NUClei.}

As has been already mentioned, there is no antheridium or male organ in this form, and so there is no possibility of nuclei coming into the ascogonium from such a source; still it is possible that some of the vegetative cells surrounding the ascogonium may fuse with its cells, and pass over nuclei. No signs of such a process were seen. The ascogonial side-walls were intact in all stages up to the dissolution of the ascogonium. There is also a possibility that nuclei may migrate into the ascogonium from the basal or tip-portions, or both, of the archicarp through the pores in the transverse walls before they are closed by the pads. Such a process would be very difficult to observe, and might easily take place without the cells showing 
any indication of a loss of contents. ${ }^{1}$ The cells in these regions at the different stages before and after the formation of the pad were carefully studied and compared, and neither was there any sign of nuclear migration, nor were there any differences noticeable in the contents, either cytoplasmic or nuclear, between these stages, but those which could be accounted for by the gradual increase in size of the cells of these regions. There was no sign, therefore, of a nuclear migration from these sources. The fusing nuclei very probably belong to the cells of the ascogonium only.

The next point to determine was whether the nuclei in these ascogonial cells were capable of fusing only with nuclei from another ascogonial cell or whether they only fused with others of the same cell, or again, whether they fuse indiscriminately with any ascogonial nucleus. Young ascogonia were examined in which the pads were still present, and it was found that fusions took place even in these young ascogonia (Fig. 5). If we neglect the possibility of nuclei migrating previously to the formation of the pad and, indeed, there seems to be no reason whatever for supposing this process to have occurred ; it must be admitted that the nuclei in any one ascogonial cell are able to fuse with one another. When the cells are in open continuity, however, there is nothing to prevent nuclei wandering freely about, and I am strongly of the opinion that then the nuclei fuse indiscriminately, though, in the absence of any differentiation between the nuclei of the different cells, there can be no positive proof.

\section{The Ascogenous Hyphae.}

Some time after the nuclei of the ascogonium have begun fusing, and, as far as could be ascertained, soon after the formation of the secondary perforations, the ascogenous hyphae begin to be developed. It has already been mentioned that no special central cell is differentiated, as in Ascobolus furfuraceus ; similarly here no special cell gives rise to ascogenous hyphae. ${ }^{2}$ In some ascogonia two, three, or four cells have been seen to take part in their formation. I have only seen one ascogonium in which there are traces of ascogenous hyphae being given off by all the ascogonial cells, here four in number (Fig. I4). Whether this is the usual process or not could not be satisfactorily ascertained, for as the ascogenous hyphae soon lose their connexion with the ascogonium, and as the cells probably do not all begin forming ascogenous hyphae at precisely the same time, this particular point is difficult to elucidate. Cells, however, from all portions

${ }_{1}^{1}$ Harper records (20) that in Pyronema the nuclei move over from the antheridium to the ascogonium leaving behind most of the cytoplasm.

${ }^{2}$ Dangeard (10) mentions that in one of his sections of Ascobolus glaber he thought that two ascogonial cells were giving rise to ascogenous hyphae, but he is not quite sure of this. From his figures it would appear that the ascogonial cells in this species are very similar in size, and it is possible that his observation was correct. 
of the ascogonium seem capable of giving rise to ascogenous hyphae. The two or three cells nearest the tip-portion of the archicarp were more usually found in this condition than those in any other portion of the ascogonium, and the balance of evidence seems in favour of the view that all the ascogonial cells are potentially capable of giving off these hyphae, but that usually those ascogenous hyphae which are formed from the tip-cells are found sufficient for the purpose of emptying the whole ascogonium of its contents, and that therefore the two or three lowest cells do not usually form ascogenous hyphae of their own, but pass on their protoplasm and nuclei to those cells that do. It is possible, however, that all of these ascogonial cells usually give off ascogenous hyphae.

Dangeard (10) is of the opinion that in Ascobolus the nuclei of all the archicarp cells, except the central cell, degenerate. The very open communication between the ascogonial cells, and the fact that ascogenous hyphae are given off by more than one cell in Ascophanus carneus, makes it seem very unlikely that any such phenomenon should occur in this species. This point, nevertheless, received careful consideration, and in no ascogonium was any evidence of such a wholesale degeneration of nuclei obtained. It does, indeed, often happen that some nuclei are left behind in the ascogonium (Figs. $21 \quad a$ and $b, 22$ ) after the development of the ascogenous hyphae, and that these undergo a process of degeneration; but these nuclei are about equally distributed amongst the cells of the ascogonium and not situated in any special cell or cells. Miss Welsford (27) has already denied the degeneration of the nuclei of the cells on either side of the central cell of Ascobolus furfuraceus, and my observations are against the occurrence of any such phenomenon in Ascophanus cameus.

The ascogenous hyphae when first formed are full of dense protoplasm which contains numerous nuclei. Harper (21), in his paper on Phyllactinia, attempted to account for the series of binucleate cells in the ascogenous hyphae of certain ascomycetous fungi by comparing the nuclear fusion in the ascus with that in the basidium. Because of this theory special attention was paid to these hyphae to try and find whether any such series of binucleate cells could be found in this form, and if so, in what manner it was brought about. No such series, however, was found, and the nuclei in the newly-formed hyphae seemed to be quite irregularly arranged.

Since the appearance of Claussen's preliminary note on Pyronema (8)in which the author claims that the male and female nuclei do not fuse in the ascogonium, but enter the ascogenous hyphae in pairs, and that their descendants fuse to form the primary ascus nucleus-the search has been renewed, and other series of sections have been examined, but with the same result. The nuclei are not arranged in pairs, except at the formation of the asci. The ascogenous hyphae, when they have grown out to some little distance, form septa, and the major part of the protoplasm is aggregated F f 2 
in the end cells which grow out. The cells near the ascogonium get more and more vacuolated, and their nuclei seem to degenerate. Sometimes a solitary nucleus may be seen in a cell of an ascogenous hypha; at other times as many as three or even five in one section. This latter case is somewhat against the view of a binucleate series of nuclei in the ascogenous hyphae. Four nuclei in one cell may be regarded as an example of a nuclear division not yet followed by a cell-division but the presence of five nuclei is incapable of any such explanation.

The ascogenous hyphae make their way between the cells of the fruit and amongst the bases of the paraphyses, branching much during the process, and also twisting in all directions. The portions embedded in the hypothecium are distinguished from the surrounding cells by paucity of content, and the parts in the region of the paraphyses by the density of the protoplasm. As the paraphyses themselves are much richer in protoplasmic contents than the hypothecial cells, it will be seen that the difference between these two portions of the ascogenous hyphae is very marked indeed. A similar state of affairs is reported by Harper for Ascobolus (20). As in this latter genus it seems very probable that the young ascogenous hypha obtains most of its nourishment from the surrounding tissue and not from the ascogonium, from which indeed it soon loses its connexion, the young ascus probably receives most of its food from the paraphyses.

After the emptying of the ascogonium by the ascogenous hyphae, the remaining nuclei degenerate (Figs. I4, 2I $a$ and $b, 22$ ), passing through stages very much like those described by Davis (12) for the degenerating nuclei in the oogonium of Saprolegnia, becoming more and more vacuolate, swelling up, and finally disappearing. The ascogonium-walls are forced inwards by the pressure of the surrounding cells, and soon the whole structure is unrecognizable. In the case of ascogonia which are vertically placed in the fruit, the ascogonial cells are first drawn out (Fig. 2 I $a$ and $b$ ) before their total disorganization.

\section{The Ascus.}

The ascogenous hyphae bend over at the tips (Fig. I $5 a$ ) and form the characteristic bent end, from the penultimate cell of which the ascus is formed with the usual fusion of two nuclei (Figs. I5 $a, b, c, d, \mathbf{1} 6$ ). This latter process is sometimes somewhat delayed.

As the ascus gets larger and larger a series of vacuoles make their appearance above and below the nucleus, and the protoplasm in these regions becomes more and more vacuolate until only the protoplasm immediately around the nucleus and at the extreme tip of the ascus is free from vacuoles (Fig. I9). At the tip the protoplasm is extremely dense, especially at that portion where the lid is formed, by which the ascus opens. 
The ascus by this time has taken on the club-shape so commonly found in the Ascobolaceae, and resembles very much the figures which Overton gives of Thecotheus Pelletieri (24).

Although material has been fixed at all times of the day, no stages have been seen either in the divisions of the ascus-nuclei or in the formation of the wall of the spore. Most of the fruits that were examined were, however, much too young to show these stages, and those that were old enough were not examined in as much detail as the younger ones, so that it is still possible that such stages may be amongst the sections, and that such processes do take place during the day. The characteristic number of spores-eight-is formed in the ascus.

\section{General Considerations.}

In recent years evidence in favour of the sexuality of the Ascomycetes has been rapidly accumulating, and several cases of fertilization, both of the normal and of the so-called reduced type have been described.

Professor Harper has reported normal fertilization by means of male and female organs in Sphaerotheca $(18,19)$, Erysiphe (19), Pyronema (20), and Phyllactinia (21), and Blackman and Fraser (6) have confirmed his observations on Sphaerotheca.

The first recorded case of reduced fertilization was described by Blackman and Fraser (7) in Humaria gramulata. Since then Miss Fraser has recorded other similar cases in Lachnea stercorea (14) and Humaria rutilans (15), and Miss Welsford a similar process in the development of Ascobolus furfuraceus (27).

Claussen (8) has recently described the state of affairs in Pyronema confluens, in which, as he holds, the male and female nuclei, arranged in pairs, pass out of the ascogonium into the ascogenous hyphae, and the sexual fusion is delayed until the formation of the ascus. From this one observation he concludes that in no ascomycete is there more than one fusion, and that the rule obtains throughout the group that the sexual fusion is delayed until the ascus formation.

Miss Fraser and Miss Welsford (17) have already pointed out that although such a shifting of the sexual fusion is possible, yet there is no reason whatever to regard it as the rule, rather than the exception, amongst the Ascomycetes.

In the paper that I have just quoted, the well-authenticated case of Sphaerotheca, in which there has been shown to be two fusions, is urged against this view of Claussen's, and also the fact of double reduction, which Miss Fraser has observed, in the ascus of Humaria rutilans and other forms $(15,17)$.

As this theory of Claussen's is fully discussed by Miss Fraser and 
Miss Welsford (17) in their paper 'Further contributions to the Cytology of the Ascomycetes', the subject need not be further entered into here.

In Ascophanus carneus we have another example of a reduced fertilization, and in this case also two fusions have been seen, the one in the ascogonium representing the sexual fusion, and the other, the fusion which is the usual preliminary to the formation of the ascus.

The ascogonium of this form presents many points of similarity to that of Ascobolus furfuraceus, the two most striking differences being that, in the latter, only one ascogonial cell gives off ascogenous hyphae, and that, as has been described by Harper (19) and confirmed by Miss Welsford (27), the cells of the archicarp are uninucleate when first formed. This latter statement has been denied by Dangeard (10) who says that the ascogonium is multinucleate at its inception. The mere fact that the cells of the ordinary vegetative mycelium of the fungus are multinucleate at once presents a difficulty, when one tries to imagine the way in which an ascogonium with uninucleate cells could originate on it. Neither Harper nor Miss Welsford used pure cultures, nor did they succeed in obtaining anything like a complete series from the uninucleate to the multinucleate condition of the archicarp. In the absence of such a series it is not at all impossible that the fruit with the uninucleate ascogonium may belong to another fungus, and not to Ascobolus furfuraceus. It will also be remembered that the descriptions of this young fruit given by Harper and Miss Welsford do not agree, the former recording well-marked pores between the ascogonial cells and the latter finding no pores at all at this stage. Dangeard describes pores even in the earliest stages of the ascogonium of Ascobolus, and he regards these pores as comparable to the ones found in the vegetative hyphae. This description of their structure and of their origin as multinucleate cells would agree more closely with what I have found in Ascophamus carneus, but whether the ascogonium of Ascobolus is multinucleate at its origin or uninucleate, I think that it is comparable to that of Ascophanus. ${ }^{1} \quad$ Miss Fraser and Miss Chambers (16) mention that the archicarp of Ascobolus furfuraceus seems to have a sterile stalk, but whether it has a sterile tip-portion I have been unable to make out from the published accounts : however,Taf. XII, Fig. 44 of Harper's paper (19), and Pl. IV, Fig. 5 of Miss Welsford's paper (27) would seem to suggest that this is so.

In Ascophamus carneus the ascogonial cells are very nearly of the same size, fusions take place in all of them, and the majority, if not all, of these cells give off ascogenous hyphae; for these reasons I regard all of the ascogonial cells of Ascophamus as female. In Ascobolus, as Miss Welsford has pointed out, the central cell must be regarded as female, but the other

1 The ascogonium of Melanospora parasitica, from the description given by Kihlmann (22), would also seem to be very similar to that of Ascophanus, but the details of its structure and development have yet to be worked out. 
ascogonial cells may be regarded either as female or vegetative. If we allow that the ascogonia of these two forms are comparable structures, in the light of what has been said above for the ascogonium of Ascophamus, it would seem more than probable that all the cells of the ascogonium of Ascobolus furfuraceus are female. The isolated case which Dangeard (10) mentions, in which there was a suggestion of ascogenous hyphae coming off from two ascogonial cells in Ascobolus glaber, seems to strengthen this view.

Any attempts which have been made to trace out a monophyletic origin for the Ascomycetes have been met with two great difficulties: the various types of the male and also of the female organ met with in this group. Miss Fraser and Miss Chambers (16) in their paper on Aspergillus herbariorum have successfully disposed of the first problem, but the second still presents considerable difficulties.

In Ascophanus carneus we find an archicarp that is comparable to that of Ascobolus furfuraceus, and that also presents several points of similarity with the archicarps of other forms.

Like the Lichen archicarp it is divisible into three portions, a stalk, an ascogonial, and a tip-portion, which very probably represents a trichogyne, although in the absence of any trace of a male organ it is impossible to make sure of this. The number of cells in each of these portions of the archicarp, both in $A$. carneus and in Lichens, varies considerably; primary pores are also found connecting the cells, and these are broken down to form larger secondary pores. It is true that the pores in the 'trichogyne' portion of Ascophanus are permanently closed, but this is probably connected with the loss of function of this organ, while in the Lichen the secondary pores in this region are probably formed to allow of the passage of the male nucleus to the ascogonial region. In both plants a considerable number of cells give rise to ascogenous hyphae. The only marked point of difference lies in the uninucleate nature of the cells of the Lichen archicarp. Miss Fraser has suggested that the ascogonium of $A$ scobolus bridges over the gap between the uninucleate ascogonium and the coenogamete, but, as I have already shown, it cannot be regarded as proved that the ascogonium of Ascobolus is composed of uninucleate cells at its origin. Miss Dale (9) mentions that in Gymnoascus the ascogonium is uninucleate at the start and becomes multinucleate later, but in the case of neither of the species that she examined does Miss Dale give an account of the number of nuclei in the vegetative cells. It seems probable from the short, preliminary communications that Barker $(1,2)$ has made on Ryparobius that this genus may throw some light on the subject, and the appearance of his full account will be awaited with interest.

Fraser and Chambers, in discussing the different types of female organ in the Ascomycetes, point out that although several types are known in which the trichogyne is multicellular, yet the only case in which it 
is reported that the ascogonium is multicellular is in the archicarp of the Lichen type. A complete investigation of such a form has yet to be made, and these authors suggest that the ascogonium may really be unicellular before fertilization and develop into a multicellular structure afterwards as in Boudiera, ${ }_{1}^{1}$ Gymnoascus, and the Erysiphaceae. Whether this is really so further research alone can tell, but the facts so far recorded seem to be against this view. Baur (3) found that in Collema there were, from the beginning, a number of ascogonial cells, and he records the fact that after fertilization these cells divide, so that the number of ascogenous cells is thus increased. Darbishire (11) when working at Physcia pulverulenta paid especial attention to this point, and says that he does not find in this species the state of affairs which Baur stated for Collema; the ascogonial cells do not divide after fertilization. If, as Fraser and Chambers (16) suggest, the unfertilized ascogonium of the Lichen type is unicellular, it does not seem likely that the above-mentioned observers would have missed this point, especially as they were looking for divisions of the ascogonial cells.

It has been pointed out that the ascogonium of such forms as Boudieva, Gymnoascus, and the Erysiphaceae develops into a multicellular structure after fertilization. This structure, although analogous to the ascogonium, which is multicellular before fertilization, can scarcely be regarded as its homologue. Such a multicellular structure would seem to have some advantages over the unicellular form, as in Humaria granulata and Lachnea stercorea, in that it allows of the origin of ascogenous hyphae over a larger surface. The ascogenous hyphae are therefore, at their origin, placed under conditions better suited for their nourishment than when they arise crowded together on a more limited area. The septate ' ascogonium ' of the Erysiphaceae might possibly be regarded as a structure adapted to the conditions best suited to the nourishing of the ascogenous hyphae. It will be remembered that in Gymnoascus (9) each of the cells of the septate 'ascogonium ' gives rise to ascogenous hyphae, while in what would seem to be the undoubtedly homologous structure in Erysiphe only one cell produces ascogenous hyphae; in Phyllactinia, however, it would seem to be probable that more than one cell of the septate 'ascogonium ' produces branches, and it is possible that in the ancestral form of the Erysiphaceae all the cells branched. Further research on allied forms might throw some light on this point, which seems to me to present another argument in favour of the reduction of the Erysiphaceae. It is possible that a comparable series of reductions is present in the Ascobolaceae, but is here shown in a series of ascogonia septate before fertilization.

Dangeard (10) records that in Ascophamus ochraceus he finds ascogonia like those of Pyronema, but without antheridia. On the strength of this he proposes to remove the genus Ascophanus from the Ascobolaceae. As the 
genus Ascophanus agrees very well with the characters of the Ascobolaceae (except in the ascogonium of $A$. ochraceus mentioned above), and as the ascogonium of Ascophamus carneus agrees very well with those of Ascobolus and Lasiobolus, it would seem desirable to retain the genus in the Ascobolaceae.

In concluding I wish to express my thanks to Prof. V. H. Blackman for the valuable help and advice he has given me throughout the progress of this investigation.

\section{Summary.}

I. The vegetative mycelium of Ascophanus carneus is composed of multinucleate cells. There is a pore in the middle of the transverse wall of each cell, and on either side of this pore a number of granules are situated.

II. The fruit is formed by one ascogonium, but the ascogonia often arise very close together, and in such cases the fruit-coverings of two adjacent ascogonia become common (cp. Aspergillus). In such cases each ascogonium still forms a separate hymenium.

III. The archicarp of Ascophanus carneus is of the type which Woronin described as a 'scolecite'. It is composed of a varying number of cells. It may be very simply curved but usually is curled round and round in a very complicated manner. There is no male organ.

IV. The cells of the archicarp are at first very similar, but they soon differentiate into three regions more or less marked off from each other. The middle portion behaves as an ascogonium, and the two side portions remain vegetative. The number of cells which go to make up these different portions varies greatly. The apical portion of the archicarp may possibly represent a trichogyne.

$\mathrm{V}$. Each of the ascogonial cells is provided with a small pore in the middle of the transverse wall. This pore is guarded by small granules which early fuse together to form a pad closing the pore. After a time this pad disappears, and then a large secondary pore, as wide as the diameter of the pad, is found in the transverse wall. The ascogonial cells seem to be multinucleate at their formation.

VI. Nuclear fusions seem to take place in all of the ascogonial cells, and have been noted even in cells still cut off from their neighbours by the pads mentioned above. No nuclear migration into the ascogonium was noticed, either from the surrounding vegetative cells or from the other portions of the archicarp.

VII. All the ascogonial cells seem to have the power of giving off ascogenous hyphae, but it is not certain whether they always do so. Each ascogonial cell is regarded as female, and the nuclear fusions noticed within these are regarded as a reduced type of fertilization in which the female nuclei fuse in pairs. 
VIII. The tips of the ascogenous hyphae bend over in the usual manner, and the ascus is formed from the penultimate cell after the fusion of the two nuclei which it contains.

IX. The ascus contains eight spores with walls of medium thickness. These spores germinate only in alkaline media (in one case a spore was observed to germinate in an acid medium) and under the influence of a medium temperature (about $35^{\circ} \mathrm{C}$.).

\section{REFERENCES.}

1. Barker, B. T. P.: The Development of the Ascocarp in Ryparobius. Report Brit. A.A.S., Southport, I903, p. 849 .

2. : Further Observations on the Ascocarp of Ryparobius. Report Brit. A.A.S., I904.

3. BAur, E. : Zur Frage nach der Sexualität der Collemaceen. Ber. d. Deutsch. Bot. Ges., xvi, I898, p. 303 .

4. - Untersuchungen über die Entwickelungsgeschichte der Flechtenapothecien. Bot. Zeit., lxii, I904, p. 2 I.

5. Bi.ackman, V. H.: On the Fertilization, Alternation of Generations and General Cytology of the Uredineae. Ann. Bot., xviii, 1904, p. 323.

6. - and Fraser, H. C. I. : Fertilization in Sphaerotheca. Ann. Bot., xix, I905, pp. 567-9.

7. : On the Sexuality and Development of the Ascocarp in Humaria granulata. Proc. Roy. Soc., London, Ser. B., lxxvii, I9o6, p. 354.

8. Claussen, P.: Zur Kenntnis der Kernverhältnisse von Pyronema confuens. Ber. d. Deutsch. Bot. Ges., xxv, I907, p. 586.

9. Dale, E.: Observations on the Gymnoascaceae. Ann. Bot., xvii, I903, p. 57 I.

10. Dangeard : L’origine du périthèce chez les Ascomycètes. Le Botaniste, I0, Juillet I907.

11. Darbishire, O. V.: Über die Apothecienentwickelung der Flechte Physcia pulverulenta (Schreb.) Nyl. Jahrb. f. wiss. Bot., xxxiv, I899, p. 329.

12. Davis, B. M.: Oogenesis in Saprolegnia. The University of Chicago, I903.

13. De BAry, A.: Comparative Morphology and Biology of the Fungi, Mycetozoa, and Bacteria. Oxford, 1887 .

14. Fraser, H. C. I. : On the Sexuality and Development of the Ascocarp in Lachnea stercorea. Ann. Bot., xxi, I907, p. 349 .

15. - Contributions to the Cytology of Humaria rutilans. Ann. Bot., xxii, I908, p. 35 .

16. Fraser, H. C. I., and Chambers, H. S. : The Morphology of Aspergillus herbariorum. Ann. Mycol., v, I907, "p. 420.

17. Fraser, H. C. I., and Welsford, E. J.: Further Contributions to the Cytology of the Ascomycetes. Ann. Bot., xxii, 1908, p. $46_{5}$.

18. Harper, R. A. : Entwickelung des Peritheciums bei Sphaerotheca Castagnei. Ber. d. Deutsch. Bot. Ges., xiii, I 895 , p. 475 .

19. Jahrb. f. wiss. Bot., xxix, I896, p. 655 .

20. - Sexual Reproduction in Pyronema confluens and the Morphology of the Ascocarp. Ann. Bot., xiv, I900, p. 32 I.

21. $:$ Sexual Reproduction and the Organization of the Nucleus in certain Mildews. Publ. Carnegie Inst. Washington, No. 37, 1905. 
22. Kihlmann, O. : Zur Entwickelungsgeschichte der Ascomyceten. Acta Soc. Sc. Fennicae, xiv, I 885 , p. 309

23. Massee, G.: British Fungus Flora, vol. iv, 1895 .

24. Overton, J. B. : The Morphology of the Ascocarp and Spore-formation in the many-spored Asci of Thecotheus Pelletieri. Bot. Gaz., xlii, 1906, p. $45^{\circ}$.

25. RABENHORST: Kryptogamen-Flora. III. Abth. : Ascomyceten.

26. Ternetz, C.: Protoplasmabewegung und Fruchtkörperbildung bei Ascophanus carneus, Pers. Jahrb. f. wiss. Bot., xxxv, I900, pp. 273-309.

27. WelsFord, E. J. : Fertilization in Ascobolus furfuraceus. New Phyt., vi, 1907, p. I 36.

28. Woronin, M.: Zur Entwickelungsgeschichte der Ascobolus pulcherrimus, Cr. u.s.w. Beitr. zur Morph. u. Physiol. der Pilze, zweite Reihe, I866, p. I.

\section{EXPLANATION OF PLATE XXVIII.}

\section{Illustrating Mr. Cutting's paper on the Ascocarp of Ascophanus carneus.}

All the figures have been drawn with the aid of the camera lucida and the apochromatic objective $2 \mathrm{~mm}$. apert. I.30 of Zeiss, Figs. I-4, 9-I $3,{ }^{-1} 5^{-1} 7$ and 20 , with the ocular I2, and Figs. $5-8,14,18,19,21 a$ and $b$, and 22 , with the ocular 6 . Fig. I has been reduced about two-thirds in reproduction. The sections from which Figs. 16 and 17 were drawn were stained with Heidenhain's haematoxylin and erythrosin, the others with Fleming's triple stain.

Fig. I. Restoration of typical archicarp made from several sections of a young fruit. $\times$ II 80 (about).

Figs. 2 and 3. Sections through cells of a young uncovered archicarp showing numerous nuclei. $\times \mathrm{I} 77 \mathrm{O}$.

Fig. 4. Section showing transverse wall between contiguous ascogonial cells with the small primary pore and the granules on either side of it. $\times$ I 770 .

Fig. 5. Ascogonium showing nuclear fusions in one of the cells entirely cut off from the adjacent cells by pads over the pores. In the transverse wall of the lowest cell a large, secondary pore is shown. The drawing is taken from the ascogonium which is reconstructed in Fig. I, and is built up from two successive sections. $\times 830$.

Fig. 6. Ordinary vegetative cell of fruit showing numerous nuclei. $\times 830$.

Fig. 7. Cells from surface of fruit showing one of the secondary hyphae with pits in the transverse walls of the cells. $\times 830$.

Fig. 8. Section through a young fruit showing three ascogonial cells in open contact. Only in the two lowest cells were any signs of fusion seen. $\times 830$.

Fig. 9. Sections from the same ascogonium as Fig. 5, showing fusion-stages. $\times 1770$.

Figs. IO, II, and I2. Sections from the same ascogonium as Fig. 8, showing different fusion. stages in two contiguous cells. The secondary pore is well shown in Fig. II. $\times$ I 770.

Fig. I3. Group of nuclei from an ascogonium showing nuclei before fusion, two in the act of fusing and a fusion nucleus. $\times$ I 770 .

Fig. I4. Old ascogonium showing three portions; 'trichogyne,' ascogonium, and stalk-cells (most of the last have become disorganized). Ascogenous hyphae are shown coming off from all the ascogonial cells, but the majority are given off by the two cells adjacent to the 'trichogyne'. (Drawn from several sections.) $\times 830$.

Fig. I5 $a, b, c, d$. Different stages in the formation of the ascus. $\times$ I 770 .

Fig. I6. Fusion of nuclei to form ascus-nucleus. $\times 1770$.

Figs. I7 $\left(x 1_{770}\right)$, 18 , and $19(\times 830)$. Young asci of slightly different ages。

Fig. 20. Section of ascospore as seen when still enclosed in the ascus. $\times$ I 770 .

Fig. 2I $a, b$. Two sections through an old ascogonium showing degenerating nuclei and traces of ascogenous hyphae. The 'trichogyne' is also indicated. $\times 830$.

Fig. 22. Section through another degenerating ascogonium. The secondary pores are well shown here. The nuclei are filled in from several sections. $\times 830$. 
Annals of Botany,
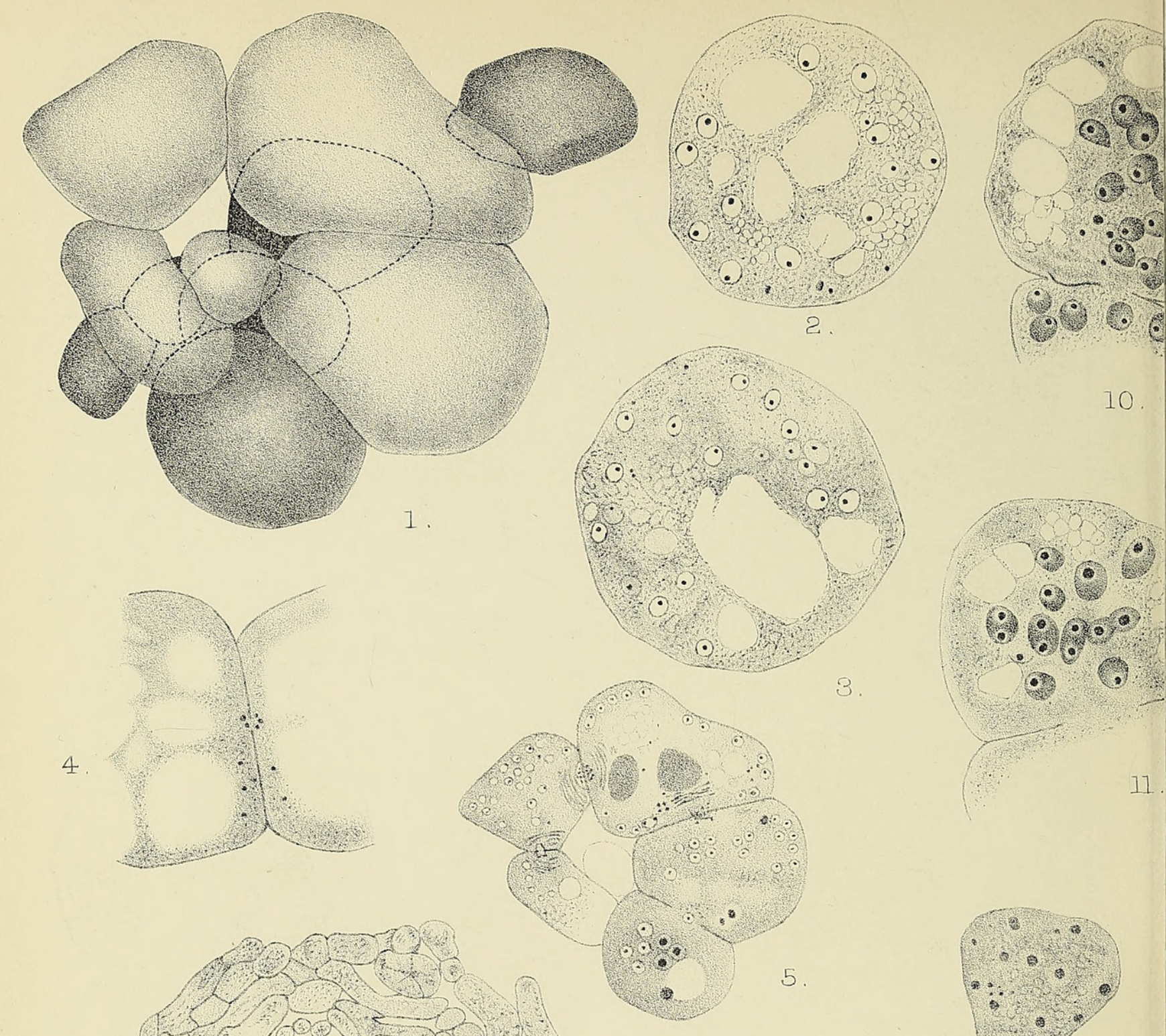

10

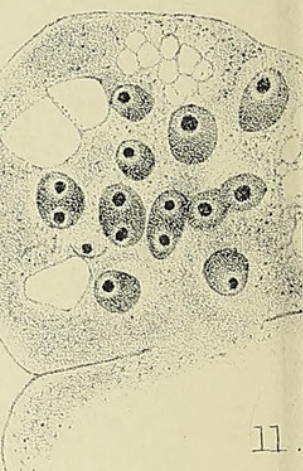

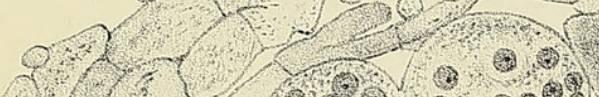
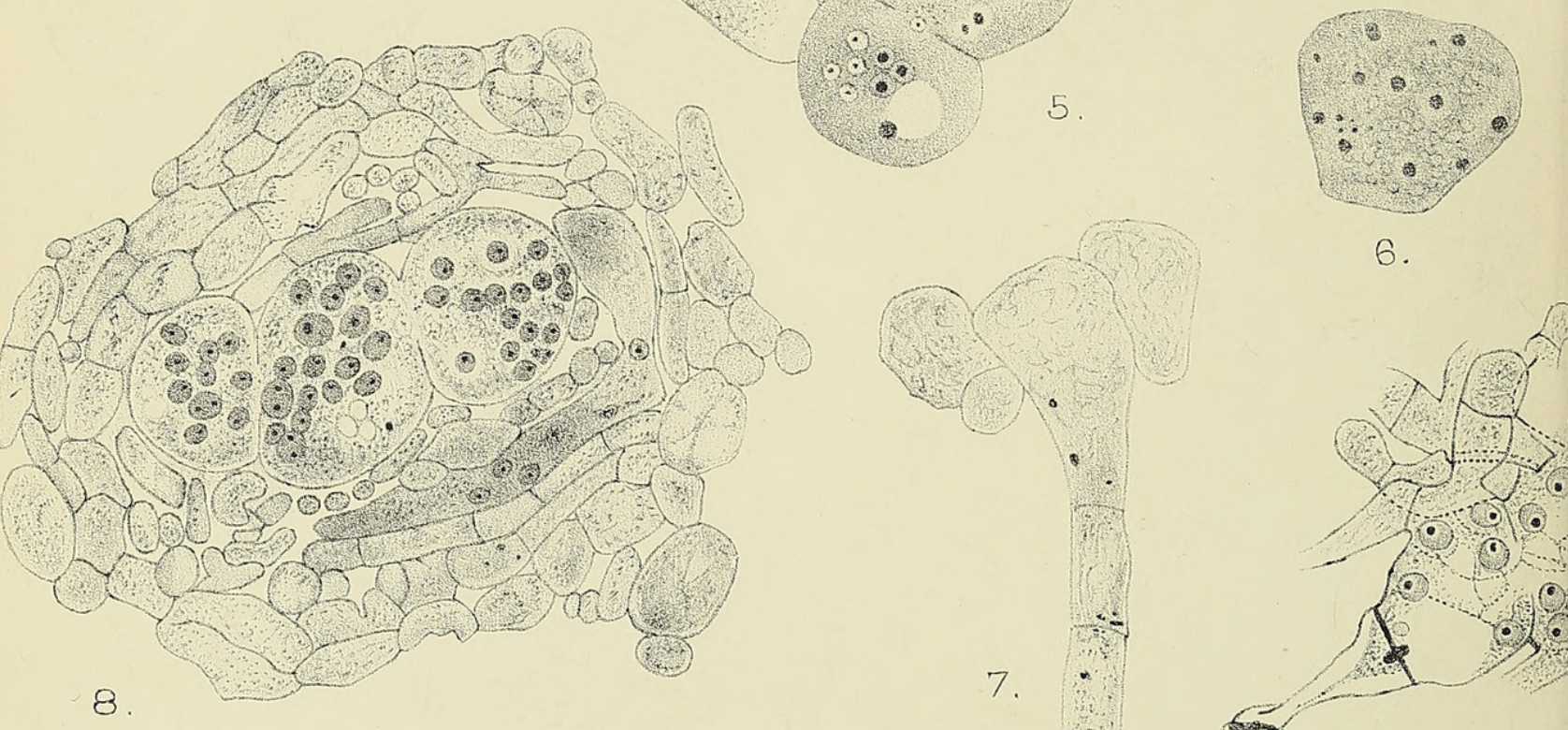

6.

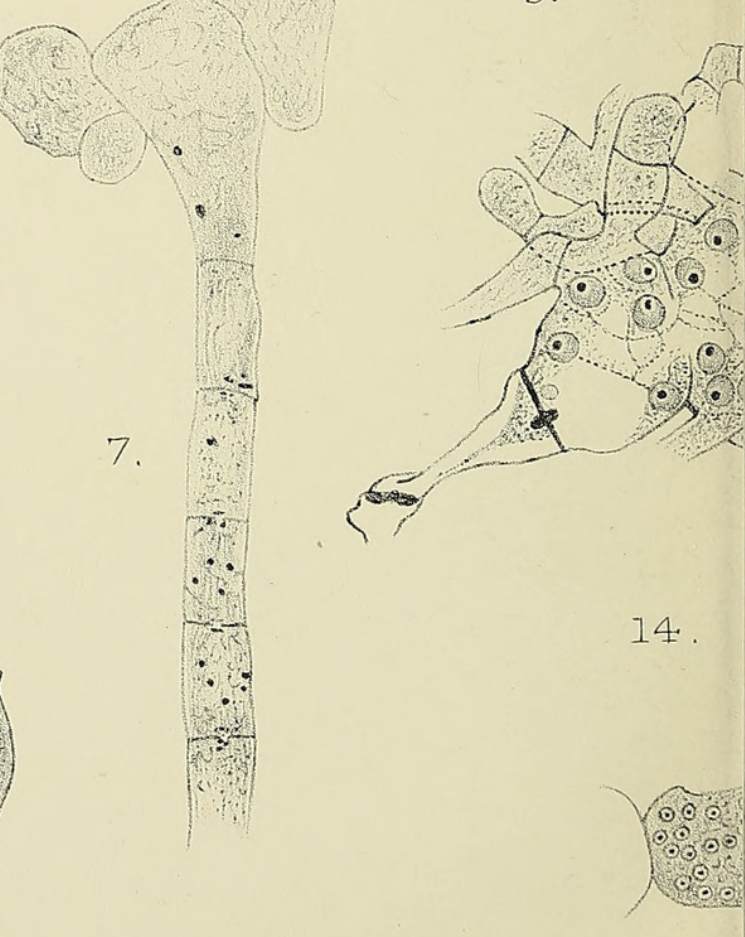

9. 


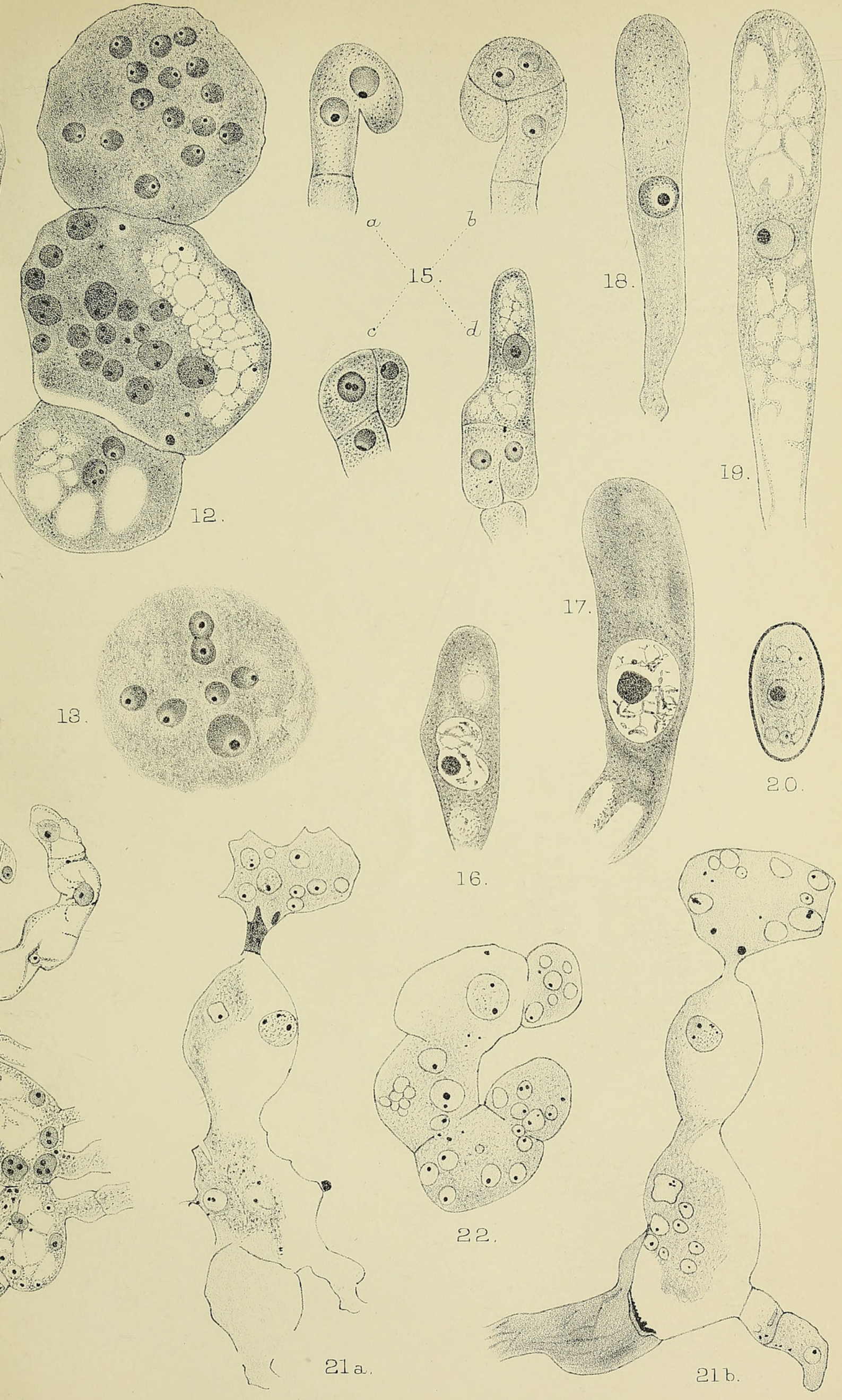




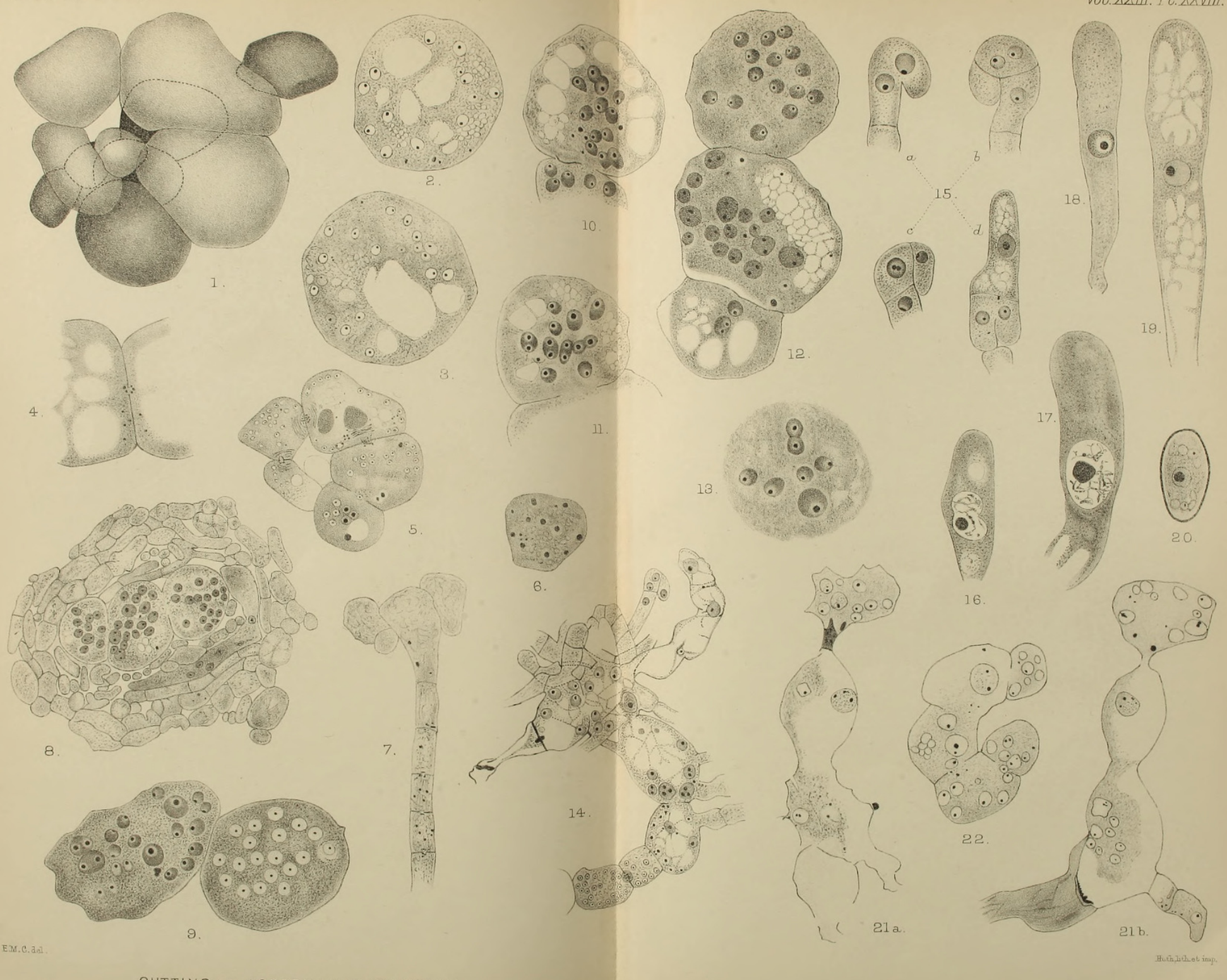




\section{$2 \mathrm{BHL}$ Biodiversity Heritage Library}

Cutting, E. M. 1909. "On the sexuality and development of the ascocarp in Ascophanus carneus, Pers." Annals of botany 23, 399-417. https://doi.org/10.1093/oxfordjournals.aob.a089228.

View This Item Online: https://www.biodiversitylibrary.org/item/236540

DOI: https://doi.org/10.1093/oxfordjournals.aob.a089228

Permalink: https://www.biodiversitylibrary.org/partpdf/318963

\section{Holding Institution}

Smithsonian Libraries

\section{Sponsored by}

Biodiversity Heritage Library

\section{Copyright \& Reuse}

Copyright Status: Not in copyright. The BHL knows of no copyright restrictions on this item.

This document was created from content at the Biodiversity Heritage Library, the world's largest open access digital library for biodiversity literature and archives. Visit BHL at https://www.biodiversitylibrary.org. 